\title{
Hindrances to Women Advancing to Principals' Decision Making Positions in Secondary Schools in Kenya: Evidence of Convergence and Divergence Views among Current Male and Female Principals
}

\author{
Andrew Makori \\ Murang'a University of Technology, Murang'a, Kenya. \\ andrewmakori@hotmail.co.uk
}

\begin{abstract}
The study set out to investigate the views of current female and male secondary school principals regarding barriers or hindrances to women teachers becoming secondary school principals in a County in Kenya. The study employed a quantitative survey approach and involved 18 female and 22 male principals who were purposively selected from forty secondary schools. Questionnaires were used to collect data. The resulting data was analysed using the SPSS (Software package for social science). The study findings indicate that while there was some degree of convergence among female and male principals, there also existed a wide range of divergence views among female and male principals in regarding factors that hinder women teachers from becoming secondary school principals, among the schools that took part in this study. The study concludes that barriers or hindrances to women advancement into educational leadership were differentially perceived between female and male secondary principals. One recommendation is that a large scale study was necessary in order to develop a full understanding of both male and female principals perceptions regarding factors that hindered women from advancing to leadership positions in secondary schools in Kenya.
\end{abstract}

Keywords: Hindrances, female principals, male principals, convergence views, divergence views, women, secondary school, Kenya, barriers, county

\section{INTRODUCTION}

Lack of significant representation of women in decision making positions in education (administration, management and leadership) was a widespread phenomenon in both developing and developed countries. It is an area that has attracted the attention of many scholars and researchers (Combat, 2014; Marshall, 1992; Msila, 2013; Uwezeyimana, Modiba and Mathevula, 2014; Turner, Gozalas and Wood, 2008; Young, 2004). Lack of representation has been attributed to a number of barriers or hindrances, among them, race, culture, ethnicity, religion, marital status, discriminatory hiring and promotion practices, lack of mentoring systems from families and colleagues, lack of networking, lack of female role models and lack of support from colleagues and administrators, among others (Moorosi, 2010; Uwizeyimana, Modiba and Mathevula, 2014; Chisholm, 2001; Baldoni, 2013). It is therefore argued that poor representation of women in decision making roles deprives the sector, important skills, qualification, experiences, expertise and qualities such as inclusiveness, openness, consensus building, innovation, collaboration, collegiality and meticulousity, that they posses (Combat, 2014). This articles or paper presents the findings based on the views of male and female principals in relations to the barriers or hindrances that contribute to the current situation of underrepresentation of women in secondary schools leadership, management and administration positions. Evidence indicates existence of convergence and divergence views among male and female principals. 
Hindrances to Women Advancing to Principals' Decision Making Positions in Secondary Schools in Kenya: Evidence of Convergence and Divergence Views among Current Male and Female Principals

\section{LITERATURE REVIEW}

\section{Underrepresentation of Women in Educational Decision Making Positions}

Review of literature indicate that women underrepresentation in educational decision making position is a common feature internationally (Msila, 2013). For instance, Lunyilo, Tikoko and Simatwa (2014) report that in England and Wales only 36\% females are in management positions. This is further supported by Coleman (2001) who rate women in educational management, leadership and administration positions in the UK as a minority. Also, in England and Wales (UK), just fewer than half of the primary schools have a woman head teacher, while in secondary schools about one in six has a woman head (Mathipa and Tsoka, 2001). In Ethiopia the number of women in headship position has been described as extremely low (Turner, et al, 2008). In South Africa women occupies fewer than $10 \%$ of school management positions (Msila, 2013). Further, in South Africa, more women occupy leadership and management positions in primary schools than in secondary schools (Msila, 2013). Another study revealed that in Gauteng province (South Africa) 7.8\% of men and 3.3\% of women occupied top management positions in education (Mathipa and Tsoka, 2001). In the United States of America, women were the majority in the classroom, but those who shared in formal headship positions was significantly small (Mathipa and Tsoka, 2001). In Uganda, Sperando and Kadoga (n.d) report that leadership of secondary schools suffers from a more pronounced underrepresentation of women. Women underrepresentation in education leadership and management has also been reported in Australia (Brown and Irby, 2005; Eagly and Carli, 2003; Shakeshaft, 1989; 1999).

Explanations or reasons offered to justify underrepresentation of women in this regard include (Sperando and Kagoda, n.d):

- Lack of women who have the minimum qualifications needed to apply for leadership positions;

- Lack of interest of qualified candidates in leadership positions;

- Hidden barriers to women applying for and being appointed to the leadership position.

Underrepresentation of women in educational leadership and management positions occurs in very interesting contexts or situations. For instance, in some of those situations, women are the majority of teachers in the classrooms or they actually outnumber men teachers in the classrooms (Mathipa and Tsoka, 2001). Secondly, women have similar skills and qualifications as their men counterparts and thirdly, women have shown to posses superior leadership styles traits (Combat, 2014).

The rationale for female representation in education leadership positions in educational systems in the world over is based on the following arguments (Lunyilo et al, 2014; Combat, 2014):

- To provide a gendered perspective on educational change and development;

- To ensure social justice through gender equity at leadership and decision making levels;

- To contribute to sensitivity within schools for the well-being of adolescent girls;

- To provide role models of women decision-makers to girls beginning to consider career choices;

- To sufficiently utilize skills, experience and qualifications that women posses.

In order to arrest the inequalities in educational leadership positions in the education profession, some approaches have been adopted although the result or outcome is mixed. For instance, in Sudan a special university has been established to cater only for women. Also in 2002 Zimbabwe established a university for the purpose of uplifting women (Jeruto and Keprop, 2014). In 1995 the $4^{\text {th }}$ conference on women called for government worldwide to create a gender sensitive education system in order to ensure full and equal participation of 
Hindrances to Women Advancing to Principals' Decision Making Positions in Secondary Schools in Kenya: Evidence of Convergence and Divergence Views among Current Male and Female Principals

women in educational administration and policy decision making (Sperando and Kagoda, n.d.). Measures that have been employed to address gender equality in South Africa, for instance, include, the constitution, the establishment of a commission of Gender Equality, the gender policy framework and the various strategies and policies in particular departments and the establishment of the Department of Women, Children and Persons with Disabilities (Diko, 2014). However, despite the policies, strategies and mechanism put in place by the South African government to improve gender equality in government institutions evidence indicates that educational leadership still favours males and resists change (Diko, 2014). Also, a study conducted in Gauteng province in South Africa, involving female teachers who had been promoted into leadership position indicate that, 'they became frustrated and ultimately left the education sector' (Diko, 2014: 826- 827). Msila (2013), reports that the status of women at workplace is changing but at a sluggish pace.

In Kenya, constitutional reforms e.g. the 2010 constitution offers a frameworkfor equitable gender representation but implementation has proved elusive (The Conservation, 2017). According to 2010 constitution there should be no more than two-thirds of the members of elective bodies can be of the same gender (Conservative, 2017). However, there are still barriers and biases operating at multiple levels that inhibit the use of women in political leadership (Conservative, 2017). Women in Kenya constitute 19 per cent of the members of parliament falling below the 30\% constitutional requirements (Conservative, 2017). Rwanda, among Sub-Saharan countries, has done much better at ensuring equitable gender representation, for instance women representation in parliament is at $63.8 \%$ (Conservative, 2017).

\section{Factors Attributed to Underrepresentation of Women}

It is evidence from the preceding section that underrepresentation of women in higher levels of administration is widespread and continues to persist.

This underrepresentation has been attributed to various barriers or hindrances, some of whom are considered in this section. These barriers discourage a majority of women who attempt to transit in leadership positions. They make it difficult for them to attain senior positions (Young, 2004). Using the South Africa situation or context, Moorosi (2010: 17) identifies three levels or phases of challenges to women in their journey to principalship:

- Phase one: this is anticipation phase, which prepares women for management roles;

- Phase two: This is the acquisition phase, which deals mainly with the problem even suitably qualified and experienced women face when seeking access and entry into organizational management positions;

- Phase three: This is a performance phase, where the actual management function is performed. The focus in this phase is that even women who have attained these positions still face lack of mentors and support from their colleagues.

The argument Moorosi (2010: 17) is making using the three phases is that "women seem to get stack at the third phase because of insufficient support even when they have made tremendous efforts at the two preliminary phases, i.e. anticipation phase and the acquisition phase".

Other factors that affect and define the experiences of women include (Uwizeyimana, Modiba and Mathevula, 2014): race, culture and ethnicity, religion and language, and marital status. Some of the reported cultural perspectives include gender stereotype and women's lack of willingness to relocate (Uwizayimana, Modiba and Mathvula, 2014). Gender stereotyping is linked to sex-role stereotyping (Prentice and Carranza, 2002). Women's lack of willingness to relocate is linked to family responsibilities which make them unwilling to accept positions which require them to relocate or travel long distances from home (Uwizayimana, Modiba and Mathevula, 2014). This may further suggest that, female educators do not want to apply for the posts that are 
Hindrances to Women Advancing to Principals' Decision Making Positions in Secondary Schools in Kenya: Evidence of Convergence and Divergence Views among Current Male and Female Principals

far away even when they meet the requirements for the posts, because they do not want to stay away from their families (children and husband) (Uwizayimana, Modiba and Methevula, 2014). Lack of colleagues and family support coupled with excessive family responsibility constraint women from availing themselves for school management positions (Uwizayimana, Modiba and Mathevula, 2014).

Other identified hindrances to women's journey to leadership and management positions include discriminatory hiring and promotion practices, lack of mentoring systems in the teaching profession, lack of support systems from family and colleagues, lack of the ability to network, lack of female role models and lack of support from colleagues and administrators (Chisholm, 2001; Baldoni, 2013). In order for women to advance in their leadership and management career, there is an urgent need to network, collaborate and coordinate with colleagues and beyond (Rhodes and Brundrett, 2006).

There is also an element of mistrust in women leadership in some communities or societies caused by tradition and culture, among other factors (Lumby, 2003; Mestry and Schmidt, 2012). Lumby (2003) further explains that some communities do not trust women to be appointed as school managers because that is an important job which demands the seriousness that only man could provide. Man is always perceived as superior by society, irrespective of his circumstances (Msila, 2013). Such societal perception regarding men, leads to men dominating women and in that way obscures women's strength and abilities (Msila, 2013).

Brown and Ralph (1996) in Sperando and Kagoda (n.d) talk of internal and external barriers, which keep women from advancing in leadership. They explain that internal barriers included the effect of socialization and sex stereotyping, while external barriers related to the structures of the education system that locked women into low-power, low-visibility, dead-end jobs and hence limited their performance and opportunities. Socialisation and gender stereotyping have also been regarded as additional internal barriers (Turner, Gozalez and Wood, 2008).

Further, Kagoda (2000) identities other barriers women must overcome before accessing or ascending into leadership and management roles in the education system, they include:- family commitment, low self-esteem, and lack of opportunities and encouragement within the educational administration system.

Other barriers include (Turner et al., 2008):-

- Organisational barriers: e.g. negative stereotypes of women. Also women were perceived as lacking the ability to handle discipline at school (Logan, 1999);

- Working conditions and sex discrimination: e.g. old fashioned sexist attitudes Also male subordinates have been found to be intimidating to women at times, indicating directly that they did not want to work for a woman.

- Socialisation and sex role stereotyping: e.g. traditional stereotype which portray women as socially incongruent as leaders and thus hinder their integration into various organisations.

- Hiring practices and recruitment, influenced by such factors as culture, gender stereotype assumptions and biases that can lead to employers overlooking talented candidates and limiting their access to the talents pool;

- Family and home responsibilities: these factors restricted women aspirants or because those who were involved in hiring believed that women could be hindered by family commitments;

- Gendered cultural and social values: Cultural and social values divide the society into male and female arenas. They also define social expectations for male and female. 
Hindrances to Women Advancing to Principals' Decision Making Positions in Secondary Schools in Kenya: Evidence of Convergence and Divergence Views among Current Male and Female Principals

The barriers discussed above, identified by Turner and his colleagues explain the low participation of women in educational leadership.

Together, these barriers or hindrances help to account for the underrepresentation of women in school management and leadership positions.

\section{METHODOLOGY}

The study was conducted to increase understanding or awareness of how current male and female secondary school principals perceived factors that hindered female teachers from becoming or attaining principalship position in selected secondary schools within a county in Kenya. The study adopted a quantitative research approach and employed questionnaires survey to collect data. The questionnaire format consisted of closed, open-ended and rating scale items, in order to increase diversity as well as reducing question fatigue (Watson and Coombes) as cited in Onderi and Makori (2013).

The open-ended sections of the questionnaire, allowed respondents to expand or clarify some of their closedended responses. And in that way, offered insight to the researchers and readers regarding their perspectives in terms of factors that limit female teachers' chances of progressing to secondary school leadership roles in a county.

The study respondents consisted of current female (18) and male (22) school principals who were purposively selected from secondary schools in a county in Kenya.

Respondents were made aware of the purpose of the study and the implications of their involvement. They consented to be involved in the study and were assured of confidentiality and anonymity.

Data obtained through closed-ended items resulted in quantitative data and was analysed using SPSS producing descriptive data. The open-ended information or data resulted in qualitative data and was thematically or categorically analysed, and used to clarify or expand on the quantitative data.

\section{Presentation of Result(s)}

\section{Background Information}

- Respondents characteristics- the total of respondents was 40 ; male $(n=22)$ and female $(n=18)$ representing $55 \%$ and $45 \%$ respectively;

- The respondents taught various subjects, Science (36\%), Art (50\%) and Humanities (13.6\%);

- Number of years in the teaching career: 0-5 years (4.5\%); 12 - 17 years (18.2\%) and over 17 years (77.3\%);

- Educational qualifications: Bachelors of Education Degree (63.6\%); Master of Education Degree (31.8\%) and $\mathrm{PhD}(4.5 \%)$;

- Age range of participants (principals): 31-41 (19.2\%); 42-52 (76.2\%) and 50-63 (4.5\%);

- Gender of deputy principals of the current principals: Male (63.6\%); Female (36.4\%);

- Age range of the deputy principals of the current principals: 31-41 (33.3\%); $42-52$ (61.9\%) and 53- 63 (4.5\%);

- Gender of the previous deputy principals: Male (78.9\%) and Female (21.1\%);

- School location: rural schools (72.7\%); urban schools (18.2\%) and Peri-urban (9.1\%). 
Hindrances to Women Advancing to Principals' Decision Making Positions in Secondary Schools in Kenya: Evidence of Convergence and Divergence Views among Current Male and Female Principals

\section{Barriers or Hindrances}

Table1. Showing barriers or hindrance score by male and female principals

\begin{tabular}{|c|c|}
\hline & \\
\hline 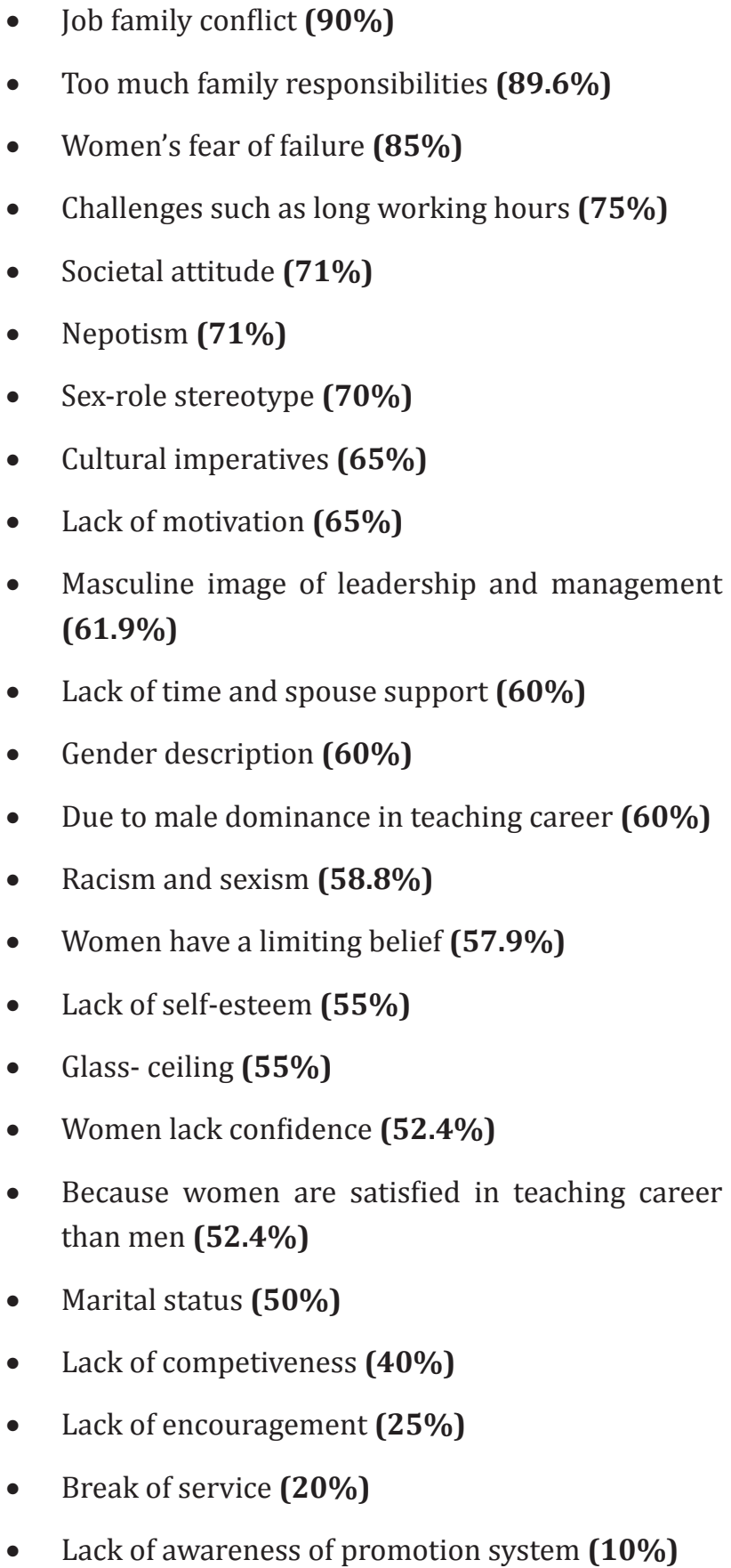 & 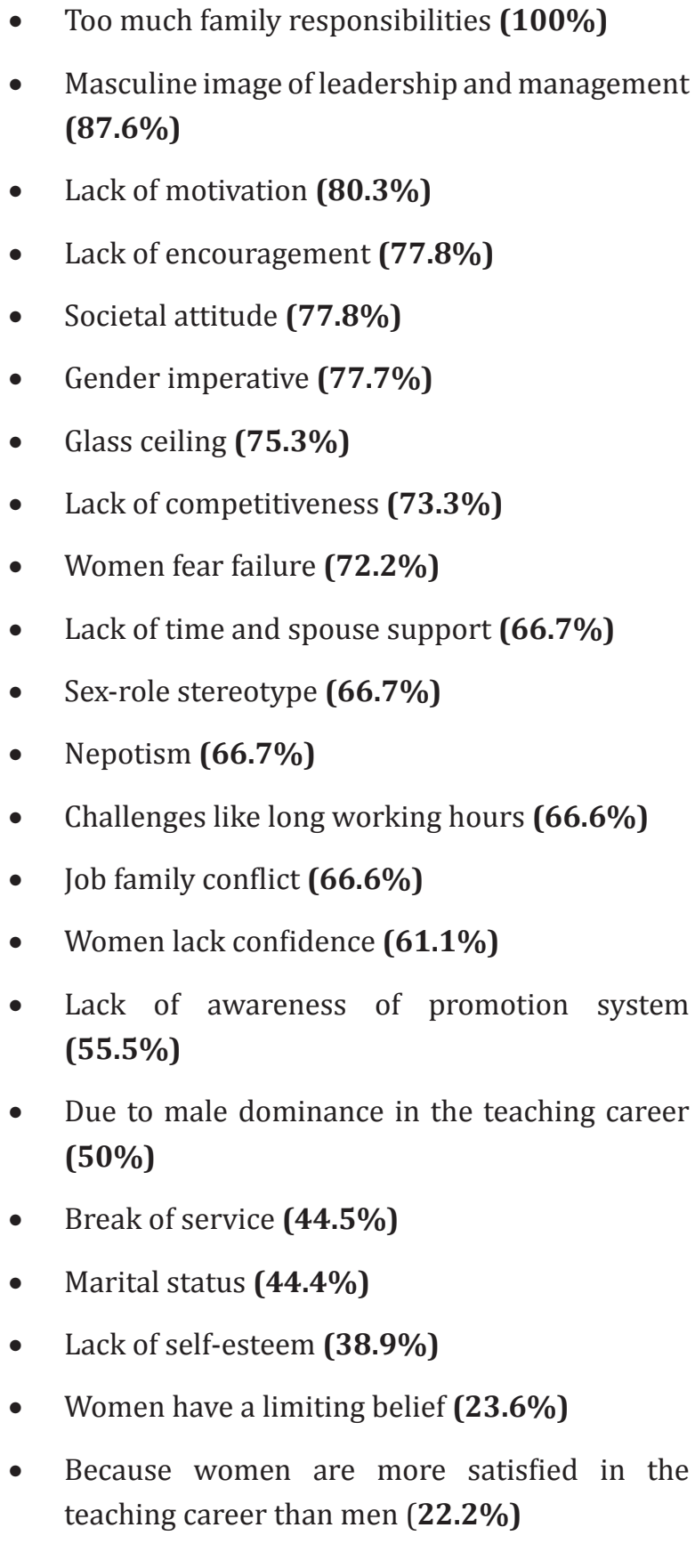 \\
\hline
\end{tabular}

Based on the scores in table1 above, the barriers or hindrances have been grouped into three categories, namely high (A), medium (B) and low (C). See tables 2- 4 below. 
Hindrances to Women Advancing to Principals' Decision Making Positions in Secondary Schools in Kenya: Evidence of Convergence and Divergence Views among Current Male and Female Principals

A] High Level Barriers [70- 100\%]

Table2. High level barriers or hindrances

\begin{tabular}{|c|c|}
\hline Male Principals & Female Principals \\
\hline - Lack of job family support & - Too much family responsibilities \\
\hline - Too much family responsibilities & - Masculine image of leadership and management \\
\hline - Women's fear of failure & - Lack of motivation \\
\hline - Challenges such as long working hours & - Lack of encouragement \\
\hline - Societal attitude & - Gender description \\
\hline - Sex-role stereotype & - Glass-ceiling \\
\hline & - Lack of competitiveness \\
\hline & - Women fear of failure \\
\hline & - Societal attitudes \\
\hline
\end{tabular}

In table 2 two above male and female principals have identified 6 factors and 9 factors high level factors that are very responsible for women under-representation in leadership roles or positions in secondary schools in a county in Kenya.

\section{B] Medium Level Barriers [50- 69\%]}

Table3. Showing medium level barriers or hindrances

\begin{tabular}{|c|c|}
\hline Male Principals & Female Principals \\
\hline $\begin{array}{l}\text { - } \text { Cultural imperatives } \\
\text { - } \\
\text { - } \text { Mack of motivation } \\
\text { - } \text { Lack of time and spouse support } \\
\text { - } \text { Gender description } \\
\text { - } \text { Due to male dominance in the teaching career } \\
\text { - } \text { Racism and sexism } \\
\text { - } \text { Nepotism } \\
\text { - } \text { Lacken have a limiting belief } \\
\text { - } \text { Glass-ceiling } \\
\text { - Women lack confidence } \\
\text { - } \text { Because women are more satisfied in the teaching } \\
\text { Marital status }\end{array}$ & $\begin{array}{ll}\text { - } & \text { Lack of time and spouse support } \\
\text { - } & \text { Sex-role stereotype } \\
\text { - } & \text { Challenges such as long working hours } \\
\text { - } & \text { Job family conflict } \\
\text { - } & \text { Women lack confidence } \\
\text { - } & \text { Lack of awareness of promotion system } \\
\text { - } & \text { Due to male dominance in teaching career } \\
\text { - } & \text { Marital status }\end{array}$ \\
\hline
\end{tabular}

In table 3 above, male and female principals have identified 14 medium factors and 9 medium factors respectively.

They were also responsible for female teachers' under-representation in secondary leadership positions but with reduced or slightly lower level effect than those considered higher levels one. 
Hindrances to Women Advancing to Principals' Decision Making Positions in Secondary Schools in Kenya: Evidence of Convergence and Divergence Views among Current Male and Female Principals

\section{C] Low Level Hindrances (below 50\%)}

Table4. Showing low level barriers or hindrances

\begin{tabular}{|c|c|}
\hline Male Principals & Female Principals \\
\hline - $\quad$ Lack of competitiveness & - $\quad$ Break of service \\
\hline - Lack of encouragement & - Marital status \\
\hline - Break of service & - Lack of self-esteem \\
\hline - Lack of awareness of promotion system & - Women have a limiting belief \\
\hline & $\begin{array}{l}\text { - Because women are more satisfied in the teaching } \\
\text { career than men. }\end{array}$ \\
\hline
\end{tabular}

These may be considered as factors with least impact in relations to women progression to headship position $\mathrm{s}$ in secondary schools in the county. Men and women principals in the study have identified four and five least factors respectively.

Table5. Showing divergence views of male and female principals

\begin{tabular}{|l|l|l|}
\hline Items & Male (Score) & Female(Score) \\
\hline Job family conflict & $90 \%$ & $67 \%$ \\
\hline Women fear of failure & $85 \%$ & $72 \%$ \\
\hline Challenges such as long working hours & $75 \%$ & $67 \%$ \\
\hline Nepotism & $71 \%$ & $67 \%$ \\
\hline Sex-role stereotype & $70 \%$ & $67 \%$ \\
\hline Lack of motivation & $65 \%$ & $83 \%$ \\
\hline Masculine image of leadership and management & $62 \%$ & $88 \%$ \\
\hline Gender & $60 \%$ & $77 \%$ \\
\hline Due to male dominance in teaching career & $60 \%$ & $50 \%$ \\
\hline Women have a limiting belief & $58 \%$ & $24 \%$ \\
\hline Lack of self-esteem & $55 \%$ & $39 \%$ \\
\hline Glass- ceiling & $55 \%$ & $75 \%$ \\
\hline Women lack confidence & $52 \%$ & $61 \%$ \\
\hline Because women are satisfied in the teaching career than men & $52 \%$ & $22 \%$ \\
\hline Marital status & $50 \%$ & $44 \%$ \\
\hline Lack of competiveness & $40 \%$ & $73 \%$ \\
\hline Lack of encouragement & $25 \%$ & $78 \%$ \\
\hline Break of service & $20 \%$ & $44 \%$ \\
\hline Lack of awareness of promotion & $10 \%$ & $56 \%$ \\
\hline
\end{tabular}


Hindrances to Women Advancing to Principals' Decision Making Positions in Secondary Schools in Kenya: Evidence of Convergence and Divergence Views among Current Male and Female Principals

Table5 is based on scores between male and female principals. The scores clearly indicate the degree of divergence. Based on Table5 according to men the four least important factors associated to hindrance of women to advancing to decision making positions include lack of competiveness, lack of encouragement, break of service and lack of awareness of promotion. For women the four least important factors include women having a limiting belief, women being satisfied with the teaching career than men, marital status and break of service.

Also based on table 5, the five most important factors that contribute to hindrance of women according to men include, job family conflict, challenges such as long working hours, nepotism, and women fear of failure, sexrole stereotype and lack of motivation. For women the five most important factors include, masculine image of leadership and management, lack of motivation, lack of encouragement, Gender and Glass ceiling.

While one in ten of the male principles felt that "lack of awareness of promotion" was least important in terms of hindrances, nearly three-fifths of female principals considered it important. Also, while one quarter of the male principals considered lack of encouragement as a least important hindrance factor, nearly eight in ten female principles considered it an important hindrance factor.

Table6. Showing convergence views of male and female principals based on levels

\begin{tabular}{|l|l|l|l|}
\hline Items & Male (Scores) & Female (Scores) & Levels \\
\hline Break of service & $20 \%$ & $45 \%$ & Low (Below 50\%) \\
\hline Lack of time and spouse support & $60 \%$ & $67 \%$ & Medium (50-69\%) \\
\hline Due to male dominance in teaching career & $60 \%$ & $50 \%$ & Medium (50-69\%) \\
\hline Women fear failure & $85 \%$ & $72 \%$ & High (70-100\%) \\
\hline Too much family responsibilities & $90 \%$ & $100 \%$ & High (70-100\%) \\
\hline
\end{tabular}

The convergence views are based on the levels represented in table 6 above. For instance break of service, while scores between male and female principals diverge i.e. male $20 \%$ and female $45 \%$, they both converge at score level (below 50\%) (See table 6 above). Similarly, in "too much family responsibilities", male principals scored $90 \%$, while female principals scored $100 \%$, but both converge at high level (70-100\%) indicated in table 6 . Five factors fall into this category (See Table 6 above).

\section{DISCUSSION}

This study has identified 22 factors that are responsible for the under-representation of female teachers in secondary schools leadership roles or positions in a county in Kenya. Further analysis indicate that the 22 factors could be further grouped into high, medium and low levels suggesting they could have varying effects on the advancement of women into leadership positions. There are those which were perceived to have higher effect regarding women advancement than others. But again they were differentially perceived between female and male secondary schools principals in the study. For instance 20 percent of male principals regarded 'service break' as least important factors in terms of hindering women's progression into leadership secondary schools positions compared to 45 percent female principals. Also 10 percent of male principals regarded 'lack of awareness of promotion' as an important medium level factors in terms of hindering women teachers progressing into leadership position in secondary schools in a county compared to 56 percent female principals in the study (see Table 5). This clearly indicates that there are divergent views or perception between female principals and male principals regarding factors that hinder women from attaining leadership positions in secondary schools in the study. 
Hindrances to Women Advancing to Principals' Decision Making Positions in Secondary Schools in Kenya: Evidence of Convergence and Divergence Views among Current Male and Female Principals

In terms of convergence factors, five factors were identified (See Table 6). For instance 'too much family responsibilities' is higher level convergence factor where male principals scored 90 percent, while female principals scored 100 percent. They are grouped into convergent level because the percentage between male and female principals is very close and therefore fall into same level. Also in 'lack of time and spouse support' male principals scored 60 percent, while female principals scored 67 percent. Percentagewise, both male and female principals are very close, suggesting a degree of convergence.

\section{CONCLUSION}

It is clear from this article that women are under-represented in educational decision making positions in secondary schools involved in the study, in a county in Kenya. Twenty two factors have been attributed to the phenomenon. Further analysis reveals that female and male principals study participants have varying perceptions regarding the impact of the twenty two factors identified earlier. For instance, 40 percent males and 73 percent females, attributed women under-representation in decision making position in secondary schools to lack of competitiveness. Also 52 per cent males and 22 percent females attributed women underrepresentation in decision making in secondary schools to women satisfaction in the teaching career than men. Also 10 percent males and 56 percent attributed under-representation in decision making position in secondary schools to lack of awareness of promotions. The three examples indicate a significant degree of differential perception between male and female secondary school principals regarding factors that hinder women from progressing or advancing to leadership or management positions in secondary schools.

In terms of factors that hinder women from progressing to decision making positions in secondary schools, this studies agrees with previous studies (Moorosi, 2010; Uwizeyimana, Madiba and Mathevula, 2014; Baldoni, 2013; Chrisholm, 2001). However, in addition this study contributes significant knowledge in relation to differential perception that exist between male and females principals of secondary schools, regarding the significance of those factors as barriers or hindrances to women's progressions to decision making positions.

\section{Recommendation}

Only a total of 40 secondary school principals (both male and female) were involved in this study and were drawn from only one county. This number could be increased and the study area expanded in order to obtain a clear picture of the phenomenon under consideration. Also the study could be expanded to include primary school head teachers.

\section{REFERENCES}

Blackmore, J. (1989). Educational leadership: A feminist critical perspectives on educational leadership. New York: Falmer.

Brown, G. and Irby, B. J. (2005). Increasing gender equity in educational leadership. Paper presented at the annual meeting of the American Educational Research Association, Montreal Canada.

Brown, G. and Irby, B.J. (1995). Increasing Gender Equity in Educational Leadership. Paper presented at the annual meeting at the American Educational Research Association, Montreal, Canada.

Brown, M. and Ralph, S. (1996). Barriers to women manager's advancement in education in Uganda. International Journal of Educational management, 10 (6), 18- 23.

Calvert, L.J. (1996). Speaking as white and female: A non-dominant group stand point. Organisation, 3(4):468- 485.

Chabaya, O; Rembe, S; Wadesango, N. (2009). The persistence of gender inequality in Zimbabwe: factors that impede the advancement of women into leadership positions in primary schools. South Africa Journal of Education, 29(2), 235- 251

American Research Journal of Humanities and Social Sciences

Page 10 
Hindrances to Women Advancing to Principals' Decision Making Positions in Secondary Schools in Kenya: Evidence of Convergence and Divergence Views among Current Male and Female Principals

Chisholm, L. (2001). Gender and leadership in South African educational administration. Gender and Education, 13 (4), 387- 399.

Cobb-Roberts, D. and Agosto V. (2011). Underrepresented women in Higher Education: An overview. Educational Leadership and Policy Studies. Faculty Publications www.scholarcommons.usf.edu/ cgi?article=1000\&content=els_facpub (Vols. 62 \&63 Nos. 1-4, 2011 \&2012) University of Florida.

Coleman, M. (2009). Women in Educational Leadership in Engliand. USA Bostn: MA

Coleman, M. (2005). Gender and secondary school leadership. International Studies in Educational Administration, 33(2): 3- 21.

Cotter, D.A; Hermsen, J. M ; Ovadia, S; Vanneman, R. (2001). The glass ceiling effect. Social Forces, 80(3): 655- 681.

Combat, V. F. O (2014). Women aspiring to administrative positions in Kenya municipal primary schools. International Journal of Educational Administration and Policy Studies. http://www.academicjournals. org/IJEAPS

De Beauvoir, S. (2009). The second sex. London: Randon House

De Beauvoir, S. (1972). The second sex. New York: Penguin

Dykeman, T. B. (2001). Simone de Beauvoir. Facilitator for feminist ethics. The International Journal for Field Being (G): 1-10.

Eagly, A. H. and Carli, L.L. (2003). The female leadership advantage. An evaluation of the evidence. Leadership Quarterly, 14 (6), 851- 860.

Ehrich, L. (1998). Women's under-representation in Educational Administration. Revisiting two solutions Australia and New Zealand. Journal of Law \& Education, 3(1), 49-71. www.anzela.edu.an/assets/ anzijile_3.1_-3_lisa_ehrich.pdf

Gentry, C.A.B. (1996). Women in educational leadership: the issue of under-representation of women as secondary principals. Doctoral dissertation : University of Mississippi.

Gil, D.G. (1992). Unravelling social policy. Vermont: Schenkman Books

Grant, C. (2005). Teacher leadership: gendered responses and interpretations. Agenda, 65: 44-57.

Growe, R. and Montgomery, P. (n.d.) Women and the leadership paradigm: Bridging the Gender gap. www.nationalforum. com/ElectronicJournalsvolumes/Growe/ RoslinwomenandleadershipparadigmBridgingtheGenderGap.pdf

Hymowitz, C. (2006). Women internalize stereotypes of themselves as weaker leader. The wall street Journal. Available at http://www.careerJournalinternalizestereotypesofthemes [Accessed July 2011]

Jeruto, T.B. and Kiprop, C. J. (2014). Hindrances that women face gaining to primary school leadership positions in Kenya. The case of Rongai District, Rift valley Province. International Journal of Education and Research, 2(5): 53- 60. www.ijem.com

Kagoda, A.M. (2000). The determinants of career professional development of female teachers in Uganda. Unpublished paper delivered to the Human Service today Conference, Makerere University, Kampala.

Kamau, N. (2010). Women and political leadership in Kenya. Nairobi: Henrich Boll Foundation.

Kanjere, M. M. (2001). Challenges faced by women leaders as school principals in rural areas. From http:// www.emesa.co.za/files/full/kanjere.pdf (retrieved on August, 2. 2013) 
Hindrances to Women Advancing to Principals' Decision Making Positions in Secondary Schools in Kenya: Evidence of Convergence and Divergence Views among Current Male and Female Principals

Luedtke.J.R. and Bowen, B.D. (1993). Determinants of underrepresentation of women in Aviation Education. Journal of Aviation /Aerospace education and Research, 3(4), 15- 19.

Lumby, J. (2003). Managing motivation. In: J lumby; D. middlewood, ESM Kaabwe (Eds) Managing Human Resources in South African schools. London: Commonwealth Secretariat, pp.155- 170

Lumby, J; Azaola, MC; De West, A; Skervin, H; Williamson, A. (2010). Women school principals in South Africa: leading the way. London: University of Southampton.

Madipa, E.R and Tsoka, E.M. (2001). Possible barriers to the advancement of women to leadership positions in the education profession. South African Journal of Education, 21(4): 324- 331

Mahoney, V. (1993). Breaking through women in Educational Administration. Prism

Moorosi, P. (2007). Creating linkages between private and public: challenges facing women principals in South Africa. South Africa Journal of Education, 27 (3): 507- 521

Msila, V. (2013). Obstacles and opportunities in women school leadership: A literature study. International Journal of Education Science, 5(4): 463- 470.

Onderi and Makori (2013). Understanding realities, inequalities and implications associated with policy and practice in form one selection in secondary schools in Kenya. British Journal of Art and Social Sciences, 17(1): 146-164, Retrieved from: http://www.bjournal.co.uk/BLASS.aspx

Oplatka, I (2006). Women in Educational Administration in developing countries. Journal of Education Administration, 44(6), 604- 624

Ouston, J. (1993). Women in education management. London: Longman

Ramogoshi, M. (2001). The city press, 8 July 2001. The society has different rules for men and women.

Royal Netherlands Embassy (1994). Kenya Country Gender Profile. Acts Press, African Center for Technology Studies (ACTS) Nairobi.

Sexty, R \& Starke, I (1995). Contemporary management. New York. Prentice Hall

Shakeshaft, C. (1999). The struggle to create a more gender inclusive profession. Handbook of Research of Educational Administration ( $2^{\text {nd }}$ ed.). San Francisco: Jossey-Bass

Shakeshaft, C. (1989). Women in educational administration. Newbury Park, CA: Corwin Press.

Sitterly, C; Duke, D. (1988). A woman's place: management. New Jersey: Prentice Hall.

Skenjana, N. (2009). A focus on women: politics and development. Afesis-corplan, 1-3

Stanworth, M. (1984). Gender and schooling. New York: Urwin Hyman

The Conservation (2017). Kenya's Parliament continues to stall on $2 / 3$ gender rule. www.conservation.com/ kenyns-parliament-continues-to-stall-on-the-two-thirds-gender-rule-79221

Tichy, N.M. (1996). Human Resource Management, 23 Michigan: Wiley \& Sons

Tsoka, E.M. (1999). Perceptions of women as managers. Vista Um Mamelodi.

Turner, C; Gonzalez, J. \& Wood, J. (2008). Faculty of color in Academie: what 20 years of literature tells us. Journal of Diversity in Higher Education, 1, 139- 168. 
Hindrances to Women Advancing to Principals' Decision Making Positions in Secondary Schools in Kenya: Evidence of Convergence and Divergence Views among Current Male and Female Principals

Uwizeyimana, D.E.; Modiba, N.S. and Mathevilla, N. S. (2014). Barriers to women's promotion in primary school management positions. Journal of Social Sciences, 4(3): 353- 362. http://www.krepublishers.com/02Journals/Jss/Jss-41

Valerio, A. M. (2009). Developing women leaders: A guide for men and women in organization. Oxford: WileyBlackwell.

Wakshum, L.M. (2014). Females participation in educational leadership in secondary schools of ILU ABA BORA zone. Jimma University: PhD Thesis (Unpublished). www.opendocs.ids.ac.uk/opendocs/bitstream/ handle/123456789)/5445/Letifuthesesprint-copy.pdf?sequence=1

William, C. G. (2011). Distributed leadership in South African schools: Possibilities and constraints. South African Journal of Education, 31:190-200

William, C. (1992). The glass escalator: Hidden advantages for men in the female profession. Social problems, 39(3): 253- 267.

Yukl, G. (2006). Leadership in organization (6 $6^{\text {th }}$ ed.). Upper Saddle River, NJ: Pearson-Prentice Hall

Citation: Andrew Makori. "Hindrances to Women Advancing to Principals' Decision Making Positions in Secondary Schools in Kenya: Evidence of Convergence and Divergence Views among Current Male and Female Principals". American Research Journal of Humanities and Social Sciences, vol 4, no. 1, 2018, pp. 1-13.

Copyright (C) 2018 Andrew Makori. This is an open access article distributed under the Creative Commons Attribution License, which permits unrestricted use, distribution, and reproduction in any medium, provided the original work is properly cited. 